\title{
Modifications and optimization of manual methods for polymerase chain reaction and $16 S$ rRNA gene sequencing quality community DNA extraction from goat rumen digesta
}

\author{
Durgadevi Aphale ${ }^{1,2}$ and Aarohi Kulkarni ${ }^{1}$
}

1. Praj Matrix, R \& D Center, Division of Praj Industries Ltd., 402/403/1098, Urawade, Pirangut, Mulshi, Pune, Maharashtra, India; 2. Department of Health and Biomedical Sciences, Symbiosis International University, Gram Lavale, Mulshi, Pune, Maharashtra, India.

Corresponding author: Aarohi Kulkarni, e-mail: aarohikulkarni@praj.net

Co-author: DA: durgadeviaphale@praj.net

Received: 15-02-2018, Accepted: 05-06-2018, Published online: 27-07-2018

doi: 10.14202/vetworld.2018.990-1000 How to cite this article: Aphale D, Kulkarni A (2018) Modifications and optimization of manual methods for polymerase chain reaction and 16S rRNA gene sequencing quality community DNA extraction from goat rumen digesta, Veterinary World, 11(7): 990-1000.

\begin{abstract}
Background and Aim: A critical prerequisite for studying rumen microbial community by high throughput molecular biology methods is good quality community DNA. Current methods of extraction use kits designed for samples from the different origin for rumen. This puts stress on the development of a relevant manual method for DNA extraction. The objective of this study was to modify the existing methods of community DNA extraction and thereby systematic comparison of their efficiency based on DNA yield, purity, 16S rRNA gene sequencing, and identification to determine the optimal DNA extraction methods whose DNA products reflect targeted bacterial communities special to rumen.

Materials and Methods: Enzymatic method, Chemical method, Enzymatic + Chemical method, and Enzymatic + Chemical + Physical method were modified toward evaluation of community DNA extraction from solid, squeezed, and liquid fractions of goat rumen digesta. Each method was assessed critically for nucleic acid yield and its quality. The methods resulting in high nucleic acid yield, optimal purity ratios with intact band on agarose gel electrophoresis were optimized further. Optimized methods were studied using standard polymerase chain reaction (PCR) with universal bacterial primers and 16S rRNA primers of targeted rumen bacteria. Methods denoting the presence of targeted rumen bacteria were assessed further with 16S rRNA gene sequencing and identification studies. It led toward methods efficacy estimation for molecular biology applications. Effect of rumen sample preservation on community DNA extraction was also studied. Their mean standard deviation values were calculated to understand sampling criticality.
\end{abstract}

Results: Modified Chemical method (Cetrimonium bromide) and Enzymatic+Chemical+Physical (ECP) method (LysozymeCetrimonium bromide-Sodium Dodecyl Sulfate-freeze-thaw) could extract $835 \mathrm{ng} / \mu \mathrm{l}$ and $161 \mathrm{ng} / \mu \mathrm{l}$ community DNA from $1.5 \mathrm{~g}$ solid and $2 \mathrm{ml}$ squeezed rumen digesta with purity ratios of $1.8\left(\mathrm{~A}_{260 \mathrm{~mm}} / \mathrm{A}_{280 \mathrm{~mm}}\right)$ and $2.3\left(\mathrm{~A}_{260 \mathrm{~mm}} / \mathrm{A}_{230 \mathrm{~mm}}\right)$ respectively. Comparative analysis showed the better efficiency of ECP method and chemical method toward freshly squeezed rumen digesta and solid rumen digesta. However, sample preservation at $-80^{\circ} \mathrm{C}$ for 1.5 months drastically affected the yield and purity ratios of community DNA. New protocol revealed targeted microbial community having Gram-positive as well as Gram-negative bacteria such as Prevotella ruminicola, Streptococcus lutetiensis, Ruminococcus flavefaciens, Fibrobacter succinogenes, and Selenomonas ruminantium.

Conclusion: To date, this is the first report of modified methods wherein least chemicals and steps lead toward PCR and $16 \mathrm{~S}$ rRNA gene sequencing quality community DNA extraction from goat rumen digesta. Detection of targeted rumen bacteria in solid and squeezed rumen digesta proves their strongest association with rumen fiber mat. It also marks the presence of distinct microbial communities in solid and squeezed rumen fractions that in turn differs the performance of each different method employed and yield of nucleic acid obtained. It also leaves a possibility of the presence of complex microbial consortia in squeezed rumen digesta whose DNA extraction methods need more attention. Finally, manual protocols of community DNA extraction may vary in different ruminant which suggests undertaking rigorous research in their establishment.

Keywords: 16S rRNA gene sequencing, community DNA extraction, goat, polymerase chain reaction, rumen digesta.

\section{Introduction}

The rumen microbial community is highly complex. There are approximately $10^{11}$ microbial cells per

Copyright: Aphale and Kulkarni. Open Access. This article is distributed under the terms of the Creative Commons Attribution 4.0 International License (http://creativecommons.org/licenses/ by/4.0/), which permits unrestricted use, distribution, and reproduction in any medium, provided you give appropriate credit to the original author(s) and the source, provide a link to the Creative Commons license, and indicate if changes were made. The Creative Commons Public Domain Dedication waiver (http:// creativecommons.org/publicdomain/zero/1.0/) applies to the data made available in this article, unless otherwise stated. gram of rumen contents, and these belong to many different species and genera of bacteria, Archaea, fungi, ciliate protozoa, and viruses $[1,2]$. To date, relatively few of these have been successfully cultured and characterized. The classical approaches to understanding the rich microbial diversity are heavily dependent on their ability to grow on certain synthetic media. This, in itself, is a major limitation that provided the basis for the choice of molecular analyses of rumen microbial communities, especially the uncultivable microbes. Molecular analyses, in fact, allow us to detect the 
uncultured microbial community thus yielding insight into the vastly unknown regime of rumen flora. Such kind of analyses is crucial then to determine shifts that occur within the mega microbial communities of the rumen due to external influences such as feed and water. One of the techniques that make largescale community analysis possible is high-throughput sequencing. It allows the study of extremely subtle effects of relative microbial community's compositional changes to be precisely identified in terms of absolute and relative microbial marker loci [1]. For all such crucial studies, the common prerequisite of high quality and yield DNA stands true.

DNA quality and yields, even though a critical prerequisite are highly restricted since the extraction methods do not work equally efficiently for diverse microbial groups. To date, several studies have shown that the DNA extraction method used has an impact on the microbial community representation in samples from different habitats, including the rumen. The sampling technique used from a wide choice such as oral stomach tubing, sample collection through a rumen fistula, as well as fractionation of rumen sample (into, e.g., liquid and solid), can also have an impact on microbial community parameters $[1,2]$. To minimize the variation introduced by differing methodologies,Henderson et al. [3] used PCQI method for community DNA extraction and high-throughput sequencing. While the advanced new generation sequencing methods have brought a much deeper insight into the complexity of rumen system and substantially increased knowledge related to rumen microbial diversity [4] sufficient amount of high-quality DNA as an impediment needs to be catered to.

To enable a direct comparison of the rumen community structure from different individual samples, standardization of DNA extraction methods is crucial. Several DNA extraction methods, including commercial kits, have been tried for ruminal DNA extraction [5-7]. However, commercial kits for DNA extraction are designed for non-ruminal samples and thus inherently face a challenge of effectiveness and reliability for cross usages. Vaidya et al. [8] found very clear impact of DNA extraction methods, the selected rumen fractions on downstream analysis of rumen microbial community including relative abundances of specific community members. Tatiana et al. [9] demonstrated the impact of storage of rumen cud on yield of DNA for metagenomics, abundances of specific phyla, class, or other taxa which ultimately impact diversity indices and community richness. Here, we want to systematically compare the effectiveness of a variety of community DNA extraction methods for goat rumen digesta based on the DNA integrity, yield, purity and $16 \mathrm{~S}$ rRNA gene sequencing results.

Present study evaluates the performance of modified Chemical method (CTAB), Enzymatic method (EM) (lysozyme-SDS-proteinase K), Enzymatic+
Chemical method (lysozyme-SDS-proteinase $\mathrm{K}+$ CTAB), and Enzymatic+ Chemical+ Physical method (lysozyme-SDS-CTAB-Polyvinylpyrrolidone-freeze-thaw) for community DNA extraction from goat rumen digesta. Targeted bacteria such as Ruminococcus flavefaciens and Streptococcus bovis are Gram-positive, which make it difficult to extract their DNA effectively using the manual community DNA extraction protocols. Further, extracted DNA should carry good quality and its amenability for standard polymerase chain reaction (PCR) and 16S rRNA gene sequencing is most important prerequisite.

The current research was aimed to modify the existing methods of community DNA extraction and thereby systematic comparison of their efficiency based on DNA yield, purity, 16S rRNA gene sequencing, and identification to determine the optimal DNA extraction methods whose DNA products reflect targeted bacterial communities special to rumen.

\section{Materials and Methods}

\section{Ethics approval}

Not applicable as the sample was brought from Government approved slaughterhouse.

\section{Sample collection and processing}

Fresh rumen sample was brought from Government approved slaughterhouse near Pune, Maharashtra, India, under controlled environmental conditions. The sample was either used immediately for DNA extraction or stored at $-80^{\circ} \mathrm{C}$ for $24-48 \mathrm{~h}$ without any preservatives. To evaluate the effect of long-term storage, the sample was stored at $-80^{\circ} \mathrm{C}$ for 1.5 months and was studied further. For processing, rumen digesta was squeezed and washed with the artificial saliva, which consists of $\mathrm{NaHCO}_{3}, 9.80 \mathrm{~g} / \mathrm{l}$; $\mathrm{Na}_{2} \mathrm{HPO}_{4}, 4.97 \mathrm{~g} / \mathrm{l} ; \mathrm{KCl}, 0.57 \mathrm{~g} / \mathrm{l} ; \mathrm{NaCl}, 0.47 \mathrm{~g} / \mathrm{l}$; $\mathrm{MgCl}_{2}, 0.123 \mathrm{~g} / \mathrm{l}$; and $\mathrm{CaCl}_{2}, 0.04 \mathrm{~g} / \mathrm{l}$. Before use, saliva was heated at $39^{\circ} \mathrm{C}$ and infused with $\mathrm{CO}_{2}$ for anaerobicity. Squeezed and solid rumen digesta were processed separately for DNA extraction. Solid rumen digesta was centrifuged at $12,000 \mathrm{rpm} / 10 \mathrm{~min}, 4^{\circ} \mathrm{C}$. The solid and liquid fractions were used separately. In the case of squeezed rumen digesta, the solid fraction was used after centrifugation. Both fractions were washed further with $\mathrm{NaCl}$ (HiMedia, India)EDTA (Sigma-Aldrich) $(1.5 \mathrm{M})$ thrice, before DNA extraction.

\section{Community DNA extraction}

$E M$

\section{EM1}

$1.5 \mathrm{~g}$ of fresh solid rumen digesta was centrifuged at $12,000 \mathrm{rpm} / 10 \mathrm{~min}, 4^{\circ} \mathrm{C}$. Pellet and liquid fractions were separated before DNA extraction and washed with $1 \mathrm{ml} 0.03 \mathrm{M} \mathrm{NaCl}-0.002 \mathrm{M} \mathrm{EDTA}(\mathrm{pH}: 8$ ) followed by centrifugation at $12,000 \mathrm{rpm} / 5 \mathrm{~min}, 4^{\circ} \mathrm{C}$. After three washing cycles, fractions were suspended in $100 \mu \mathrm{l} \mathrm{NaCl-EDTA}$ solution and $100 \mu \mathrm{l}$ freshly prepared lysozyme $(10 \mathrm{mg} / \mathrm{ml}$, HiMedia, India). It was 
mixed thoroughly and incubated at $37^{\circ} \mathrm{C}$ for $1 \mathrm{~h}$. It was followed by addition of $50 \mu 1(10 \%$ SDS, SigmaAldrich), $10 \mu \mathrm{l}$ proteinase K (Sigma-Aldrich), and $0.03 \mathrm{M} \mathrm{NaCl}-0.002 \mathrm{M}$ EDTA (pH: 8.0) to have total volume of $500 \mu \mathrm{l}$, followed by incubation at $55^{\circ} \mathrm{C}$ for $1 \mathrm{~h}$.

After incubation, an equal amount of chloroform: isoamyl alcohol (24:1) was added to both fractions, mixed thoroughly and incubated at room temperature for $10 \mathrm{~min}$. Whole content was centrifuged at $12,000 \mathrm{rpm} / 15 \mathrm{~min}, 4^{\circ} \mathrm{C}$. The supernatant containing crude DNA was processed twice in a similar manner. $400 \mu 1$ isopropanol (Sigma-Aldrich) and $7.5 \mathrm{M}$ ammonium acetate (HiMedia, India) were added into the washed liquid and incubated overnight at $-20^{\circ} \mathrm{C}$. Pellet was seen visually after the incubation. Entire content was centrifuged at $10,000 \mathrm{rpm} / 20 \mathrm{~min}$, $4{ }^{\circ} \mathrm{C}$. Pellet obtained was washed thrice with $70 \%$ ethanol (Fisher Scientific) by centrifugation at $12,000 \mathrm{rpm} / 20 \mathrm{~min}, 4^{\circ} \mathrm{C}$. Ethanol was removed completely after washings, and purified DNA was dried in a vacuum dryer (Thermo Fischer Scientific) without heating. Finally, the pellet was suspended in chilled $1 \times$ TE buffer (Invitrogen) and its quality was checked on a NanoDrop spectrophotometer (Thermo Fischer Scientific).

EM2

$1.5 \mathrm{~g}$ of solid and $2 \mathrm{ml}$ of squeezed rumen digesta were centrifuged at $12,000 \mathrm{rpm} / 10 \mathrm{~min}$, $4^{\circ} \mathrm{C}$. Their solid fractions were washed with $1 \mathrm{ml}$ of $0.03 \mathrm{M} \mathrm{NaCl}-0.002 \mathrm{M}$ EDTA (pH: 8) by centrifugation at $12,000 \mathrm{rpm} / 5 \mathrm{~min}, 4^{\circ} \mathrm{C}$. They were suspended in $100 \mu 10.03 \mathrm{M} \mathrm{NaCl}-0.002 \mathrm{M}$ EDTA (pH: 8 ) and a variable concentration of freshly prepared lysozyme (15 mg/ml, $20 \mathrm{mg} / \mathrm{ml}$, and $25 \mathrm{mg} / \mathrm{ml}$, HiMedia, India) followed by thorough mixing and incubation at $37^{\circ} \mathrm{C}$ for $1 \mathrm{~h}$. Remaining steps were carried out as mentioned above for method EM1.

\section{EM3}

$50 \mathrm{mg}$ to $1000 \mathrm{mg}$ of solid rumen digesta was centrifuged at $12,000 \mathrm{rpm} / 10 \mathrm{~min}, 4^{\circ} \mathrm{C}$. Their solid fractions were washed with $1 \mathrm{ml}$ of $0.03 \mathrm{M} \mathrm{NaCl}-0.002 \mathrm{M}$ EDTA (pH: 8) by centrifugation at $12,000 \mathrm{rpm} / 5 \mathrm{~min}$, $4^{\circ} \mathrm{C}$. After three washing cycles, they were suspended in $100 \mu \mathrm{l}$ of $0.03 \mathrm{M} \mathrm{NaCl}-0.002 \mathrm{M}$ EDTA (pH: 8) and $100 \mu \mathrm{l}$ freshly prepared lysozyme $(10 \mathrm{mg} / \mathrm{ml}$, HiMedia, India). They were mixed thoroughly and incubated at $37^{\circ} \mathrm{C}$ for $1 \mathrm{~h}$. Remaining steps were carried out as mentioned above for method EM1.

\section{Chemical method (CM)}

\section{CM1}

$1.5 \mathrm{~g}$ solid rumen digesta was centrifuged at $12,000 \mathrm{rpm} / 10 \mathrm{~min}, 4^{\circ} \mathrm{C}$. Pellet and liquid fractions were processed separately for DNA extraction. $2 \mathrm{ml}$ liquid fraction was used in this study. They were washed with $1 \mathrm{ml} 0.03 \mathrm{M} \mathrm{NaCl}-0.002 \mathrm{M}$ EDTA (pH: 8) by centrifugation at $12,000 \mathrm{rpm} / 5 \mathrm{~min}, 4^{\circ} \mathrm{C}$. After three washing cycles, fractions were suspended in lysis solution containing $100 \mathrm{mM}$ Tris $\mathrm{HCl}(\mathrm{pH}: 8.0$, HiMedia, India), $20 \mathrm{mM}$ EDTA (HiMedia, India), $1.4 \mathrm{M} \mathrm{NaCl}$ (HiMedia, India), and $2 \% \mathrm{w} / \mathrm{v}$ CTAB (HiMedia, India) and incubated at $65^{\circ} \mathrm{C}$ for $1 \mathrm{~h}$. Once brought to room temperature, whole content was centrifuged at $12,000 \mathrm{rpm} / 10 \mathrm{~min}, 4^{\circ} \mathrm{C}$. The supernatant containing crude DNA was suspended in equal volume of fresh and chilled Chloroform: isoamyl alcohol (24:1) and incubated at room temperature for $10 \mathrm{~min}$ followed by centrifugation at $12,000 \mathrm{rpm} / 15 \mathrm{~min}$, $4^{\circ} \mathrm{C}$. After three washing cycles, remaining steps were carried out as mentioned in the method EM1.

\section{CM2}

$1.5 \mathrm{~g}$ solid rumen digesta was processed as described in CM1. Their solid fraction was used for DNA extraction. It was added with $100 \mathrm{mM}$ Tris $\mathrm{HCl}$ (pH: 8.0, HiMedia, India), 20 mM EDTA (HiMedia, India), $1.4 \mathrm{M} \mathrm{NaCl}$ (HiMedia, India), and 0.2 to $1 \% \mathrm{w} / \mathrm{v}$ CTAB (HiMedia, India) lysis solution followed by incubation at $65^{\circ} \mathrm{C}$ for $1 \mathrm{~h}$. After incubation, remaining steps were carried out as mentioned in the method EM1.

\section{CM3}

$1.5 \mathrm{~g}$ solid rumen digesta was processed as described in CM1. Its solid fraction was used for DNA extraction. It was added with $2 \% \mathrm{w} / \mathrm{v}$ CTAB (HiMedia, India) followed by incubation at $65^{\circ} \mathrm{C}$ for $30 \mathrm{~min}$. After incubation, remaining steps were carried out as mentioned in the method EM1.

\section{CM4}

$1.5 \mathrm{~g}$ solid rumen digesta was processed as described in CM1. Its solid fraction was used for DNA extraction. It was added with $2 \% \mathrm{w} / \mathrm{v}$ CTAB (HiMedia, India) followed by incubation at $65^{\circ} \mathrm{C}$ for $2 \mathrm{~h}$. After incubation, remaining steps were carried out as mentioned in the method EM1.

\section{Enzymatic + Chemical method (ECM)}

\section{ECM1}

$1.5 \mathrm{~g}$ solid and $2 \mathrm{ml}$ of squeezed rumen digesta were processed as described in method EM1. Their solid fractions were used for DNA extraction. Fractions lysed with enzymatic method were treated with lysis solution containing $100 \mathrm{mM}$ Tris $\mathrm{HCl}(\mathrm{pH}$ : 8.0, HiMedia, India), $20 \mathrm{mM}$ EDTA (HiMedia, India), $1.4 \mathrm{M} \mathrm{NaCl}$ (HiMedia, India), and $2 \% \mathrm{w} / \mathrm{v}$ CTAB (HiMedia, India). It was incubated at $65^{\circ} \mathrm{C}$ for $10 \mathrm{~min}$. Remaining steps were carried out as mentioned in the method EM1.

\section{Enzymatic + Chemical + Physical method (ECPM)}

\section{ECPM1}

$1.5 \mathrm{~g}$ solid and $2 \mathrm{ml}$ of squeezed rumen digesta were processed as described in method EM1. Their 
solid fractions were used for DNA extraction followed by enzymatic lysis using lysozyme as described earlier. They were added with lysis solution containing $100 \mathrm{mM}$ Tris $\mathrm{HCl}$ (pH: 8.0, HiMedia, India), $20 \mathrm{mM}$ EDTA (HiMedia, India), 1.4M NaCl (HiMedia, India), and $2 \% \mathrm{w} / \mathrm{v}$ CTAB (HiMedia, India). It was mixed with $50 \mu \mathrm{l}(10 \%$ SDS, Sigma-Aldrich) followed by quick freezing of the content at $-80^{\circ} \mathrm{C}$ for $10 \mathrm{~min}$ and thawing at $65^{\circ} \mathrm{C}$. After three freeze-thaw cycles, content was brought at room temperature. It was centrifuged at $12,000 \mathrm{rpm} / 10 \mathrm{~min}, 4^{\circ} \mathrm{C}$. The supernatant containing crude DNA was suspended in equal volume of fresh and chilled Chloroform: isoamyl alcohol (24:1) and incubated at room temperature for $10 \mathrm{~min}$ followed by centrifugation at $12,000 \mathrm{rpm} / 15 \mathrm{~min}, 4^{\circ} \mathrm{C}$. After three washing cycles, remaining steps were carried out as mentioned in the method EM1.

\section{ECPM2}

This was performed similarly as ECPM1 as described above. ECPM2 was performed differently where $2.0 \% \mathrm{w} / \mathrm{v}$ PVP (PVP 40, Sigma-Aldrich) was added to the lysis solution, before three freeze-thaw cycles. Remaining steps were carried out as mentioned in the method ECPM1.

\section{ECPM3}

$2 \mathrm{ml}$ of squeezed rumen digesta was used for DNA extraction. This was performed similarly as ECPM1 as described above. ECPM3 was different where lysis solution was supplemented with $2.0 \%$ $\mathrm{w} / \mathrm{v}$ PVP (PVP 40, Sigma-Aldrich), and the number of freeze-thaw cycles was increased from three to eight. Remaining steps were carried out as mentioned in the method ECPM1.

\section{Community DNA extraction with QIAamp DNA Stool Mini Kit (Qiagen, 51504)}

$200 \mathrm{mg}$ of solid and $200 \mu \mathrm{l}$ of squeezed rumen digesta were used for DNA extraction using QIAamp DNA Stool Mini Kit (Qiagen, 51504). Effect of lysis temperature $\left(70^{\circ} \mathrm{C}\right.$ and $90^{\circ} \mathrm{C}$ for $5 \mathrm{~min}$ ) on community DNA extraction was also evaluated. Remaining steps were performed according to the instructions provided by the manufacturer.

\section{Evaluation of reliability and reproducibility of CM4} and ECPM2 methods for community DNA extraction

$1.5 \mathrm{~g}$ of solid and $2 \mathrm{ml}$ squeezed rumen digesta were used for statistical analysis of CM4 and ECPM2 methods, respectively. Details of the methods were as described above. Three independent trials were conducted with fresh solid and squeezed rumen digesta for assessing its reproducibility. Each trial was conducted in eight different vials for analyzing its reliability. Furthermore, an independent trial was conducted with $-80^{\circ} \mathrm{C}$ stored, 1 day old, and 1.5-month-old rumen digesta using CM4 and ECPM2 methods. Statistical analysis was performed using mean and standard deviation.

\section{Yield, purity, and integrity of DNA}

DNA concentrations were measured on NanoDrop spectrophotometer (Thermo Fisher Scientific). The purity of DNA was assessed spectrophotometrically from $A_{260 \mathrm{~mm}} / A_{280 \mathrm{~nm}}$ to $A_{260 \mathrm{~nm}} / A_{230 \mathrm{~nm}}$ ratios to indicate the presence of buffer salts and organic compounds as a part of DNA contamination. Integrity was determined by agarose $(2 \% \mathrm{w} / \mathrm{v})$ gel electrophoresis $(2 \mathrm{~h}, 10 \mathrm{~cm} \times 15 \mathrm{~cm}$ Mini-Sub ${ }^{\circledR}$ Cell GT, Bio-Rad) at $140 \mathrm{~V}$ using $1 \mathrm{~Kb}$ Plus DNA Ladder (N3232S, NEB) as a molecular weight marker, post-staining with $\mathrm{SYBR}^{\circledR}$ Safe DNA gel stain (Invitrogen) and illumination under UV light.

Assessing the suitability of Community DNA for PCRbased rumen microbial ecology applications

Standard PCR using 16S rRNA universal bacterial primers

The purity of community DNA for downstream applications was assessed by amplification of $16 \mathrm{~S}$ rRNA using the universal bacterial primers as $(27 \mathrm{~F}$ 5' AGAGTTTGATCMTGGCTCAG 3' and 1492R 5' TACGGYTACCTTGTTACGACTT 3'). PCR amplification was done using a $20 \mu 1$ reaction mixture containing $0.2 \mathrm{mM}$ each dNTP (N0446S, New England Biolabs), $0.5 \mu \mathrm{M}$ of each forward and reverse primer, $100 \mathrm{ng}$ DNA template, and $0.02 \mathrm{U} / \mu 1$ of Q5 Hot Start High Fidelity DNA polymerase (New England Biolabs) with $1 \times$ reaction buffer supplied by the manufacturer. Amplification was performed with a thermal cycler (Bio-Rad) using the following program: $98^{\circ} \mathrm{C}$ for $10 \mathrm{~min}$; 35 cycles consisting of $98^{\circ} \mathrm{C}$ for $10 \mathrm{~s}$; $55^{\circ} \mathrm{C}$ for $30 \mathrm{~s} ; 72^{\circ} \mathrm{C}$ for $1 \mathrm{~min}$; and a final extension step consisting of $72^{\circ} \mathrm{C}$ for $10 \mathrm{~min}$. The amplification was determined by electrophoresis of reaction product in $1 \%$ agarose gel.

\section{Standard PCR using $16 S$ rRNA primers for targeted rumen bacteria}

Community DNA samples showing PCR amplification with $1.5 \mathrm{~Kb}$ band were used for standard PCR for assessing the presence of targeted rumen bacteria using specific bacterial 16S rRNA primers, Q $5^{\circledR}$ Hot Start High-Fidelity DNA Polymerase (M0493, New England Biolabs), $0.2 \mathrm{mM}$ of each dNTPs (N0446S, New England Biolabs), $100 \mathrm{ng}$ template, and $10 \mathrm{nM}$ of forward and reverse primer (Table-1) [10,11]. PCR was performed in $20 \mu \mathrm{l}$ reaction volume using the following program: $98^{\circ} \mathrm{C}$ for $10 \mathrm{~min} ; 35$ cycles consisting of $98^{\circ} \mathrm{C}$ for $10 \mathrm{~s}$; optimized annealing temperature as given in (Table-1) for $30 \mathrm{~s} ; 72^{\circ} \mathrm{C}$ for $1 \mathrm{~min}$; and a final extension step consisting of $72^{\circ} \mathrm{C}$ for $10 \mathrm{~min}$. The amplification was determined by electrophoresis of reaction product in $2 \%$ agarose gel.

Methods which performed consistently to give intact, good quality DNA with clean PCR bands for all targeted bacteria were finalized further for 16S rRNA gene sequencing and identification studies.

\section{S rRNA gene sequencing and identification}

PCR product of each sample was subjected to electrophoresis on $2 \%$ agarose gel. $418 \mathrm{bp}$, 
$862 \mathrm{bp}, 835 \mathrm{bp}, 513 \mathrm{bp}$, and $446 \mathrm{bp}$ fragments were observed and eluted from the gel using Macherey Nagel NucleoSpin ${ }^{\circledR}$ Gel and PCR Clean-up Kit $(740609.50 \mathrm{MN})$. The forward and reverse primers were used in sequencing of the eluted PCR products; the sequencing process was done in First Base Malaysia by Sanger sequencing technique. The obtained sequences were analyzed by a BLASTN search in NCBI GenBank. A phylogenetic tree was constructed using sequence distance method.

\section{Results}

This work was aimed at the development of PCR and 16S rRNA gene sequencing quality community DNA extraction protocols through modification in existing methods followed by their optimization. In this instance, details of four different methods of community DNA extraction modified in various ways are shown in Table-2a to e and compiled together in Figure-1. Modified Enzymatic methods studied in three different sets of EM1, EM2, and EM3 differed in their nucleic acid yield (ng/ $\mu \mathrm{l})$ through their $\mathrm{A}_{260 \mathrm{~nm}} / \mathrm{A}_{280 \mathrm{~nm}}$ and $\mathrm{A}_{260 \mathrm{~nm}} / \mathrm{A}_{230 \mathrm{~nm}}$ ratios were similar in the range of 1.3 and 0.5 , respectively. EM1 processed with $10 \mathrm{mg} / \mathrm{ml}$ lysozyme, and solid-liquid fractions of rumen digesta could extract $1710 \mathrm{ng} / \mu \mathrm{l}$ and $30 \mathrm{ng} / \mu \mathrm{l}$ nucleic acid. Whereas solid and squeezed rumen digesta processed with $15 \mathrm{mg} / \mathrm{ml}$, $20 \mathrm{mg} / \mathrm{ml}$, and $25 \mathrm{mg} / \mathrm{ml}$ lysozyme in EM2 could extract successively higher nucleic acid with increasing concentration of lysozyme, where $25 \mathrm{mg} / \mathrm{ml}$ lysozyme could give $500 \mathrm{ng} / \mu 1$ and $180 \mathrm{ng} / \mu \mathrm{l}$ nucleic acid from solid and squeezed rumen digesta. In EM3, varying sample size from $50 \mathrm{mg}$ to $1000 \mathrm{mg}$ could extract highest nucleic acid of $1844 \mathrm{ng} / \mu \mathrm{l}$ from $200 \mathrm{mg}$. However, purity ratios of $\mathrm{A}_{260 \mathrm{~mm}} / \mathrm{A}_{280 \mathrm{~nm}}$ and $\mathrm{A}_{260 \mathrm{~nm}} / \mathrm{A}_{230 \mathrm{~mm}}$ obtained were poor for any set of modifications conducted in

Table-1: PCR primers used to detect targeted rumen bacteria.

\begin{tabular}{|c|c|c|c|c|c|}
\hline Primer & Sequence $\left(5^{\prime}-3^{\prime}\right)$ & $\begin{array}{l}\text { Annealing } \\
\text { temperature } \mathrm{T}_{\mathrm{a}}\left({ }^{\circ} \mathrm{C}\right) *\end{array}$ & Target & $\begin{array}{l}\text { Amplicon } \\
\text { size (bp) }\end{array}$ & References \\
\hline Bac $303 f$ & GAAGGTCCCCCACATTG & 61 & $\begin{array}{l}\text { Genus Bacteroides } \\
\text { and Prevotella }\end{array}$ & 418 & Stiverson et al. [10] \\
\hline Bac 708r & CAATCGGAGTTCTTCGTG & & & & \\
\hline Fs-f & GGTATGGGATGAGCTTGC & 64 & F. succinogenes & 446 & Stiverson et al. [10] \\
\hline Fs-r & GCCTGCCCCTGAACTATC & & & & \\
\hline Sel-Mit-f & TGCTAATACCGAATGTTG & 57 & $\begin{array}{l}\text { S. ruminantium } \\
\text { and } M \text {. multacida }\end{array}$ & 513 & Stiverson et al. [10] \\
\hline Sel-Mit-r & TCCTGCACTCAAGAAAGA & & & & \\
\hline SB-JCM5802-f & CTAATACCGCATAACAGCAT & 58 & S. bovis & 869 & Tajima et al. [11] \\
\hline SB-JCM5802-r & AGAAACTTCCTATCTCTAGG & & & & \\
\hline RF-ATCC19208-f & GGACGATAATGACGGTACTT & 62 & R. flavofaciens & 835 & Tajima et al. [11] \\
\hline RF-ATCC19208-r & GCAATCCGAACTGGGACAAT & & & & \\
\hline
\end{tabular}

${ }^{*} T_{a}$ mentioned in above table is calculated as per NEB resources and tools. $P C R=$ Polymerase chain reaction, $F$. succinogenes=Fibrobacter succinogenes, S. ruminantium=Selenomonas ruminantium, M. multacida=Mitsuokella multacida, S. bovis=Streptococcus bovis, $R$. flavofaciens=Ruminococcus flavefaciens

Table-2a: Yield and purity of community DNA extracted using modified Enzymatic method.

\begin{tabular}{|c|c|c|c|c|c|c|}
\hline $\begin{array}{l}\text { Modified Methods } \\
\text { studied }\end{array}$ & $\begin{array}{l}\text { Rumen fraction } \\
\text { used }\end{array}$ & $\begin{array}{l}\text { Quantity of rumen } \\
\text { fraction used }\end{array}$ & $\begin{array}{c}\text { Lysozyme } \\
\text { conc. }(\mathrm{mg} / \mathrm{ml})\end{array}$ & $\begin{array}{c}\text { Nucleic acid } \\
\text { conc. }(\mathrm{ng} / \mu \mathrm{l}) *\end{array}$ & $\begin{array}{l}\mathbf{A}_{260 \mathrm{~nm}} / \\
\mathbf{A}_{280 \mathrm{~nm} *}\end{array}$ & $\begin{array}{l}\mathbf{A}_{260 \mathrm{~nm}} / \\
\mathbf{A}_{230 \mathrm{~nm} *}\end{array}$ \\
\hline \multirow[t]{2}{*}{ EM1 } & Solid & $1.5 \mathrm{~g}$ & 10 & 1710 & 1.35 & 0.7 \\
\hline & Liquid & $2 \mathrm{ml}$ & 10 & 30 & 1.3 & 0.7 \\
\hline \multirow[t]{6}{*}{ EM2 } & Solid & $1.5 \mathrm{~g}$ & 15 & 400 & 1.3 & 0.3 \\
\hline & & $1.5 \mathrm{~g}$ & 20 & 480 & 1.3 & 0.3 \\
\hline & & $1.5 \mathrm{~g}$ & 25 & 500 & 1.3 & 0.3 \\
\hline & Squeezed & $2 \mathrm{ml}$ & 15 & 40 & 1.3 & 0.3 \\
\hline & & $2 \mathrm{ml}$ & 20 & 120 & 1.3 & 0.3 \\
\hline & & $2 \mathrm{ml}$ & 25 & 180 & 1.3 & 0.25 \\
\hline \multirow[t]{12}{*}{ EM3 } & Solid & $50 \mathrm{mg}$ & 10 & 101 & 1.19 & 0.44 \\
\hline & & $100 \mathrm{mg}$ & 10 & 92 & 1.32 & 0.44 \\
\hline & & $150 \mathrm{mg}$ & 10 & 25 & 1.04 & 0.64 \\
\hline & & $200 \mathrm{mg}$ & 10 & 1844 & 1.38 & 0.64 \\
\hline & & $350 \mathrm{mg}$ & 10 & 859 & 1.42 & 0.58 \\
\hline & & $400 \mathrm{mg}$ & 10 & 213 & 1.21 & 0.41 \\
\hline & & $500 \mathrm{mg}$ & 10 & 31.4 & 1.17 & 0.35 \\
\hline & & $600 \mathrm{mg}$ & 10 & 100 & 1.13 & 0.25 \\
\hline & & $700 \mathrm{mg}$ & 10 & 31 & 0.9 & 0.22 \\
\hline & & $800 \mathrm{mg}$ & 10 & 20 & 1.15 & 0.25 \\
\hline & & 900 mg & 10 & 42 & 1.23 & 0.3 \\
\hline & & $1000 \mathrm{mg}$ & 10 & 62 & 1.13 & 0.26 \\
\hline
\end{tabular}

*Data value represents mean of duplicates for each method. EM=Enzymatic method 


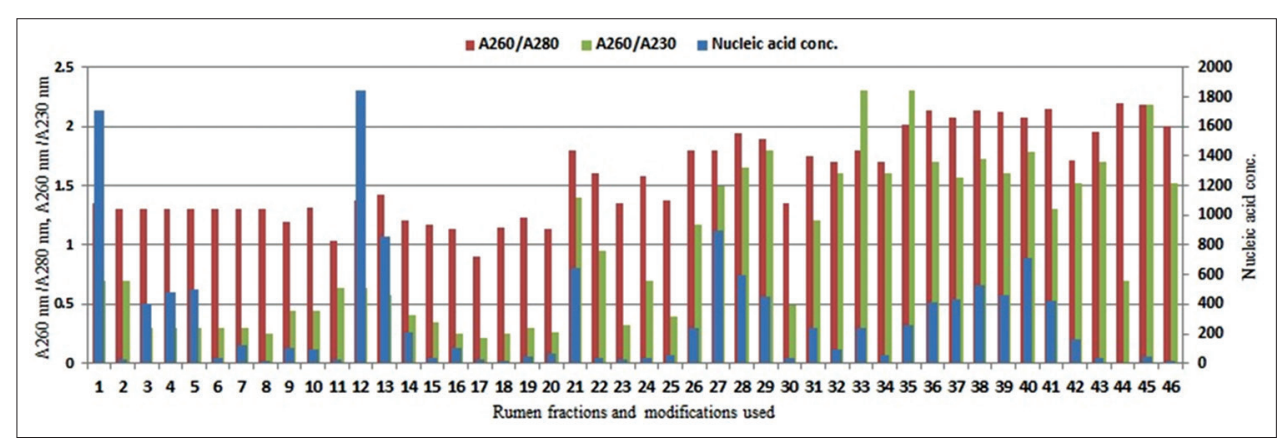

Figure-1: Efficacy of modified community DNA extraction methods. Nucleic acid concentration, $A_{260 \mathrm{~nm}} / A_{280 \mathrm{~nm}}$ and $\mathrm{A}_{260 \mathrm{~nm}} / \mathrm{A}_{230 \mathrm{~nm}}$ ratios obtained using various rumen fractions and methods modifications including, 1-2: Enzymatic method (EM)1 solid-S and EM1-solid-L (10 mg/ml lysozyme), 3-5: EM2 solid $(15 \mathrm{mg} / \mathrm{ml}, 20 \mathrm{mg} / \mathrm{ml}$ and $25 \mathrm{mg} / \mathrm{ml}$ lysozyme), 6-8: EM2 squeezed $(15 \mathrm{mg} / \mathrm{ml}, 20 \mathrm{mg} / \mathrm{ml}$ and $25 \mathrm{mg} / \mathrm{ml}$ lysozyme), 9-20: EM3-solid (50 mg, $100 \mathrm{mg}, 150 \mathrm{mg}, 200$ $\mathrm{mg}, 350 \mathrm{mg}, 400 \mathrm{mg}, 500 \mathrm{mg}, 600 \mathrm{mg}, 700 \mathrm{mg}, 800 \mathrm{mg}, 900 \mathrm{mg}$, and $1000 \mathrm{mg}$ sample size), 21-22: Chemical method (CM)1-solid-S and CM1-Solid-L ( $1 \%$ CTAB $\left.65^{\circ} \mathrm{C} / 1 \mathrm{~h}\right), 23-27$ : CM2-solid $\left(0.2-1 \%\right.$ CTAB with $\left.65^{\circ} \mathrm{C} / 1 \mathrm{~h}\right)$, 28: CM3-solid (1\% CTAB, $\left.65^{\circ} \mathrm{C} / 30 \mathrm{~min}\right), 29$ : CM4-solid $\left(1 \% \mathrm{CTAB}, 65^{\circ} \mathrm{C} / 2 \mathrm{~h}\right), 30-31$ : Enzymatic+Chemical method (ECM)1-solid and ECM1squeezed, 32-33: Enzymatic+Chemical+Physical method (ECPM)1-solid and ECPM1-squeezed, 34-35: ECPM2-solid and ECPM2-squeezed (with $0.8 \mathrm{~g} \mathrm{PVP}$ ), 36-42: ECPM3-squeezed (with $0.8 \mathrm{~g}$ PVP and 3-8 freeze-thaw cycles), 43-44: QI-solid and QI-squeezed (with $70^{\circ} \mathrm{C}$ lysis), and 45-46: QI-solid and QI-squeezed (with $90^{\circ} \mathrm{C}$ lysis).

Table-2b: Yield and purity of community DNA extracted using modified Chemical method.

\begin{tabular}{|c|c|c|c|c|c|c|}
\hline $\begin{array}{l}\text { Modified methods } \\
\text { studied }\end{array}$ & $\begin{array}{l}\text { Rumen fraction } \\
\text { used }\end{array}$ & $\begin{array}{l}\text { CTAB conc. } \\
(\% \mathrm{w} / \mathrm{v})\end{array}$ & Time (h) & $\begin{array}{c}\text { Nucleic acid conc. } \\
(\mathrm{ng} / \mu \mathrm{l})^{*}\end{array}$ & $A_{260 n m} / A_{280 n m *}$ & $A_{260 n m} / A_{230 n m *}$ \\
\hline \multirow[t]{2}{*}{ CM1 } & Solid & 2 & 1 & 644 & 1.8 & 1.4 \\
\hline & Liquid & 2 & 1 & 40 & 1.6 & 0.95 \\
\hline \multirow[t]{5}{*}{ CM2 } & Solid & 0.2 & 1 & 30 & 1.35 & 0.32 \\
\hline & & 0.4 & 1 & 40 & 1.58 & 0.7 \\
\hline & & 0.6 & 1 & 60 & 1.38 & 0.4 \\
\hline & & 0.8 & 1 & 240 & 1.8 & 1.17 \\
\hline & & 1 & 1 & 900 & 1.8 & 1.5 \\
\hline CM3 & Solid & 2 & $30 \mathrm{~min}$ & 600 & 1.94 & 1.65 \\
\hline CM4 & Solid & 2 & 2 & 450 & 1.9 & 1.8 \\
\hline
\end{tabular}

*Data value represents mean of duplicates for each method. CTAB=Cetrimonium bromide, $\mathrm{CM}=$ Chemical Method

Table-2c: Yield and purity of community DNA extracted using modified ECM.

\begin{tabular}{llccc}
\hline Modified methods studied & Rumen fraction used & Nucleic acid conc. (ng/ $\mathbf{\mu l )} *$ & $\mathbf{A}_{\mathbf{2 6 0 n m}} / \mathbf{A}_{\mathbf{2 8 0 n m}} *$ & $\mathbf{A}_{\mathbf{2 6 0 n m}} / \mathbf{A}_{\mathbf{2 3 0 n m}}$ \\
\hline ECM1 & Solid & 40 & 1.35 & 0.49 \\
& Squeezed & 240 & 1.75 & 1.2 \\
\hline
\end{tabular}

*Data value represents mean of duplicates for each method. ECM=Enzymatic+Chemical method

Table-2d: Yield and purity of community DNA extracted using modified ECPM.

\begin{tabular}{|c|c|c|c|c|c|}
\hline $\begin{array}{l}\text { Modified methods } \\
\text { studied }\end{array}$ & $\begin{array}{l}\text { Rumen fraction } \\
\text { used }\end{array}$ & $\begin{array}{c}\text { Number of } \\
\text { freeze-thaw cycles }\end{array}$ & $\begin{array}{l}\text { Nucleic acid conc. } \\
(\mathrm{ng} / \mu \mathrm{l}) *\end{array}$ & $A_{260 n m} / A_{280 n^{*} *}$ & $A_{260 \mathrm{~nm}} / A_{230 \mathrm{~nm} *}$ \\
\hline \multirow[t]{2}{*}{ ECPM1 } & Solid & 3 & 90 & 1.7 & 1.6 \\
\hline & Squeezed & 3 & 240 & 1.8 & 2.3 \\
\hline \multirow[t]{2}{*}{ ECPM2 } & Solid & 3 & 60 & 1.7 & 1.6 \\
\hline & Squeezed & 3 & 260 & 1.8 & 2.3 \\
\hline \multirow[t]{6}{*}{ ECPM3 } & Squeezed & 3 & 435 & 2.14 & 1.7 \\
\hline & & 4 & 433 & 2.08 & 1.7 \\
\hline & & 5 & 450 & 2.13 & 1.73 \\
\hline & & 6 & 460 & 2.12 & 1.6 \\
\hline & & 7 & 465 & 2.07 & 1.58 \\
\hline & & 8 & 424 & 2.15 & 1.3 \\
\hline
\end{tabular}

*Data value represents mean of duplicates for each method. ECPM=Enzymatic+Chemical+Physical method

enzymatic method. Suspension of extracted community DNA was brownish, non-uniform. Furthermore, it failed to show community DNA on agarose gel electrophoresis Figure-2a).
Modified chemical method studied in four different sets of CM1, CM2, CM3, and CM4 not only showed varying yield of nucleic acid $(\mathrm{ng} / \mu \mathrm{l})$ but also $\mathrm{A}_{260 \mathrm{~nm}} / \mathrm{A}_{280 \mathrm{~nm}}$ and $\mathrm{A}_{260 \mathrm{~nm}} / \mathrm{A}_{230 \mathrm{~nm}}$ ratios. CM1 processed 
Table-2e: Yield and purity of community DNA extracted using modified QIAamp DNA Stool Mini Kit (Qiagen, 51504).

\begin{tabular}{|c|c|c|c|c|c|c|}
\hline Kit method used & $\begin{array}{l}\text { Rumen } \\
\text { fraction used }\end{array}$ & $\begin{array}{l}\text { Quantity of rumen } \\
\text { fraction used }\end{array}$ & $\begin{array}{c}\text { Lysis } \\
\text { temperature } \\
\text { studied }\end{array}$ & $\begin{array}{c}\text { Nucleic acid } \\
\text { conc. }(\mathrm{ng} / \mu \mathrm{l}) *\end{array}$ & $A_{260 n m} / A_{280 n m *}$ & $A_{260 n m} / A_{230 n m} *$ \\
\hline \multirow{4}{*}{$\begin{array}{l}\text { QIAamp DNA Stool } \\
\text { Mini Kit } \\
\text { (Qiagen, 51504) }\end{array}$} & Solid & $200 \mathrm{mg}$ & $70^{\circ} \mathrm{C}$ & 40.1 & 1.95 & 1.7 \\
\hline & Squeezed & $200 \mu \mathrm{l}$ & $70^{\circ} \mathrm{C}$ & 10.1 & 2.2 & 0.7 \\
\hline & Solid & $200 \mathrm{mg}$ & $90^{\circ} \mathrm{C}$ & 47.3 & 2.19 & 2.18 \\
\hline & Squeezed & $200 \mu \mathrm{l}$ & $90^{\circ} \mathrm{C}$ & 13.2 & 2 & 1.52 \\
\hline
\end{tabular}

*Data values represent mean of duplicates for each method
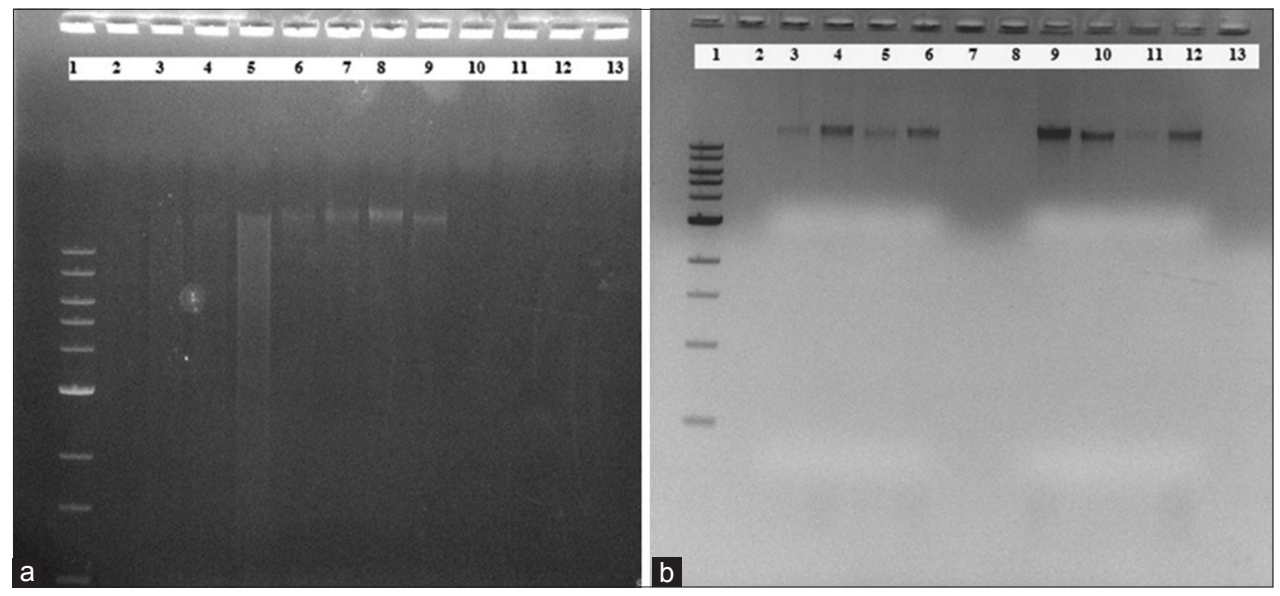

Figure-2: (a) Community DNA extraction with Enzymatic method (EM)1, Enzymatic-Chemical method (ECM) 1 and Enzymatic+Chemical+Physical method (ECPM2) methods. Community DNA extraction with $>15 \mathrm{~Kb}$ band on $1 \%$ agarose gel electrophoresis using (b) ECPM2, EM1, and ECM1 method, Lane 1: Ladder: $1 \mathrm{~Kb}$, New England Biolabs. Community DNA extraction with ECPM2 using Lane 2-5: Solid rumen digesta, Lane 6-9: Squeezed rumen digesta, EM1 using Lane 10: Solid rumen digesta, Lane 11: Blank, ECM1 using Lane 12: Solid rumen digesta, and Lane 13: Squeezed rumen digesta. (b) Community DNA extraction with CM4 method. Community DNA extraction with $>15 \mathrm{~Kb}$ band on $1 \%$ agarose gel electrophoresis using (a) CM4 method, Lane 1: Ladder: 1 Kb, New England Biolabs, Lane 2: Blank, Lane 3-6: Community DNA with CM4 method, Lane 7-8: Blank, Lane 9-12: Community DNA with CM4 method, and Lane 13: Blank.

with solid and liquid fractions of rumen digesta with $2 \% \mathrm{CTAB}$ could extract $644 \mathrm{ng} / \mu \mathrm{l}$ and $40 \mathrm{ng} / \mu 1$ nucleic acid. Community DNA extraction with solid fraction and increasing concentration of $0.2-1 \%$, CTAB was performed with $\mathrm{CM} 2$ where; increasing concentration of $\mathrm{CTAB}$ could extract successively higher nucleic acid with better purity ratios and $1 \%$ CTAB was found to be the most promising concentration. Nonetheless, CM3 and CM4 with 2\% CTAB application followed by $30 \mathrm{~min}$ and $2 \mathrm{~h}$ lysis buffer incubations resulted into nearest optimal ratios of $\mathrm{A}_{260 \mathrm{~nm}} / \mathrm{A}_{280 \mathrm{~nm}}$ and $\mathrm{A}_{260 \mathrm{~mm}} / \mathrm{A}_{230 \mathrm{~nm}}$ for the extracted community DNA. In the application of CM4, DNA suspension was white, translucent and it showed an intact band of $>15 \mathrm{~Kb}$ on $1 \%$ agarose gel electrophoresis (Figure-2b).

ECM studied with solid and squeezed rumen digesta could extract $40 \mathrm{ng} / \mu \mathrm{l}$ and $240 \mathrm{ng} / \mu \mathrm{l}$ nucleic acid; indicating about better efficacy of EC method toward squeezed rumen digesta. However, the purity ratios of $\mathrm{A}_{260 \mathrm{~mm}} / \mathrm{A}_{280 \mathrm{~nm}}$ and $\mathrm{A}_{260 \mathrm{~nm}} / \mathrm{A}_{230 \mathrm{~mm}}$ shown below optimum and it also failed to show community DNA on agarose gel electrophoresis (Figure-2a). Suspension of community DNA obtained was brownish, non-uniform. Overall, EC method could not extract a good quality community DNA.
ECPM of community DNA extraction comprises three different modifications where ECPM1 and ECPM2 were processed with solid and squeezed rumen digesta, distinctly with $2 \%$ PVP 40 application for ECPM2. Both methods could extract 240 versus $260 \mathrm{ng} / \mu \mathrm{l}$ and 90 versus $60 \mathrm{ng} / \mu \mathrm{l}$ community DNA from solid and squeezed rumen digesta. Increasing number of freeze-thaw cycles from three to eight could not increase the yield of community DNA as seen in ECPM3. $A_{260 n m} / A_{230 n m}$ ratio seen inclined toward non-optima with increasing freeze-thaw cycles though $\mathrm{A}_{260 \mathrm{~nm}} / \mathrm{A}_{280 \mathrm{~nm}}$ seen consistent in the range of 2-2.1. Overall, squeezed rumen digesta seen very suitable for ECP method of community DNA extraction for any set of modifications conducted as described in ECPM1, ECPM2, and ECPM3 (Figure 2a). Ratio of $\mathrm{A}_{260 \mathrm{~mm}} / \mathrm{A}_{280 \mathrm{~nm}}$ of 1.7 for solid rumen digesta indicates its complexity and non-feasibility toward ECPM based community DNA extraction protocols.

Community DNA extraction using QIAamp DNA Stool Mini Kit (Qiagen, 51504) followed by $70^{\circ} \mathrm{C}$ and $90^{\circ} \mathrm{C}$ lysis incubation could give highly efficient cell lysis with optimal purity ratios at $90^{\circ} \mathrm{C}$. Irrespective of lysis temperature used, solid fraction could extract higher nucleic acid than squeezed rumen 
Table-3: Statistical analysis of optimized CM4 and ECPM2 methods.

\begin{tabular}{|c|c|c|c|c|c|c|c|}
\hline \multirow[t]{3}{*}{ Community DNA extraction method } & \multirow[t]{3}{*}{ Analysis parameter } & \multicolumn{6}{|c|}{ Storage period of solid rumen digesta (at $-80^{\circ} \mathrm{C}$ ) } \\
\hline & & \multicolumn{2}{|c|}{ Fresh } & \multicolumn{2}{|c|}{1 day } & \multicolumn{2}{|c|}{1.5 months } \\
\hline & & Mean & Mean SD & Mean & Mean SD & Mean & Mean SD \\
\hline \multirow[t]{3}{*}{ CM4 } & Nucleic acid $(\mathrm{ng} / \mu \mathrm{l})$ & 835 & 714 & 459 & 417 & 811 & 436 \\
\hline & $A_{260 \mathrm{~nm}} / A_{280 \mathrm{~nm}}$ & 1.8 & 0.06 & 2.08 & 0.32 & 1.72 & 0.15 \\
\hline & $A_{260 n m}^{260 m^{\prime}} / A_{230 n m}^{280 n m}$ & 2.3 & 0.83 & 2.03 & 0.63 & 1.27 & 0.41 \\
\hline \multirow[t]{3}{*}{ ECPM2 } & 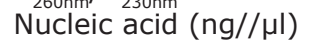 & 161 & 108 & 112 & 54 & 456 & 135 \\
\hline & $A_{260 n m} / A_{280 n m}$ & 1.8 & 0.075 & 1.86 & 0.086 & 1.43 & 0.23 \\
\hline & $A_{260 n m}^{260 n^{\prime}} / A_{230 n m}^{280 n m}$ & 2.3 & 0.18 & 2.02 & 0.15 & 0.62 & 0.17 \\
\hline
\end{tabular}
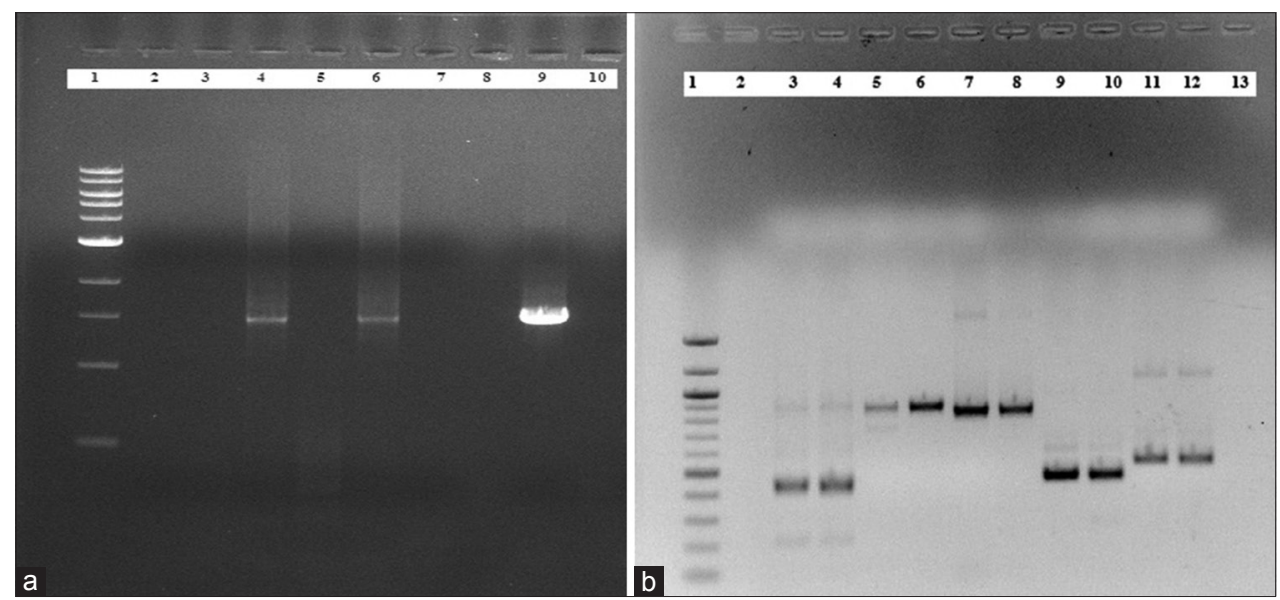

Figure-3: (a and b) Standard polymerase chain reaction (PCR) using community DNA extracted using modified methods. Standard PCR using (a) universal bacterial primers with community DNA extracted using Lane 1: $1 \mathrm{~Kb}$ ladder (New England Biolabs), Lane 2: Enzymatic method (EM)1, Lane 3: EC1, Lane 4: Enzymatic+Chemical+Physical method (ECPM)2, Lane 5: Chemical method (CM)1, Lane 6: CM4, Lane 7: CM2 methods, Lane 9: Genomic DNA of Bacillus subtilis as a positive control and Lane 10: blank (b) Specific targeted bacterial 16S rRNA gene primers and community DNA as follows. Lane 1: 100 bp ladder (New England Biolabs), Lane 2: Blank, Lane 3-4: CM4 and ECPM2 DNA with genus Bacteroides and Prevotella (418 bp), Lane 5-6: CM4 and ECPM2 DNA with Streptococcus bovis (869 bp), Lane 7-8: CM4 and ECPM2 DNA with Ruminococcus flavefaciens (835 bp), Lane 9-10: CM4 and ECPM2 DNA with Fibrobacter succinogenes (446 bp), and Lane 11-12: CM4 and ECPM2 DNA with Selenomonas ruminantium (513 bp), and Lane 13: blank.

digesta which was $40 \mathrm{ng} / \mu \mathrm{l}$ and $10 \mathrm{ng} / \mu \mathrm{l}$, respectively (Table 2e).

Irrespective of CM4 or ECPM2 methods application, statistical analysis (Table-3) showed a drastic drop in purity level of DNA by increasing sample storage period from day 0 to 1.5 months. Here, $A_{260 \mathrm{~nm}} / \mathrm{A}_{280 \mathrm{~nm}}$ and $\mathrm{A}_{260 \mathrm{~mm}} / \mathrm{A}_{230 \mathrm{~nm}}$ ratio of day 0 was observed to be $1.8 \pm 0.06$ and $2.3 \pm 0.83$ for CM4 method. It was seen to be $1.8 \pm 0.075$ and $2.3 \pm 0.18$ for ECPM2 method. Whereas, $\mathrm{A}_{260 \mathrm{~nm}} / \mathrm{A}_{280 \mathrm{~nm}}$ and $\mathrm{A}_{260 \mathrm{~nm}} / \mathrm{A}_{230 \mathrm{~nm}}$ of 1.5 month stored rumen digesta seen reduced from $1.8 \pm 0.06$ to $1.72 \pm 0.15$ and $1.43 \pm 0.23$, $2.3 \pm 0.83$ to $1.27 \pm 0.41$ and $0.62 \pm 0.17$ for CM4 and ECPM2 methods respectively. In common, nucleic acid concentration showed the highest mean standard deviation values irrespective of the storage period of solid rumen digesta.

Community DNA belongs to ECPM2 and CM4 method given $1.5 \mathrm{~Kb}$ band on $1 \%$ agarose gel electrophoresis (Figure-3a) in standard PCR using 16S rRNA universal bacterial primers. More interestingly, community DNA extracted with both methods have given PCR amplification for genus Bacteroides and Prevotella (418 bp), Streptococcus bovis (869 bp),
Ruminococcus flavofaciens (835 bp), Fibrobacter succinogenes (446 bp), and Selenomonas ruminantium (513 bp) with targeted bacterial 16S rRNA gene primers (Figure-3b) and optimized annealing temperature (Table-1). Moreover, 16S rRNA gene sequencing and identification confirmed the presence of $P$. rumnicola, $S$. lutetiensis, $R$. flavofaciens, $F$. succinogens, and $S$. ruminantium in goat rumen. However, genus Bacteroides and Mitsuokella multacida were not detected in this study. NCBI BLAST analysis revealed $95 \%, 99 \%, 98 \%, 99 \%$, and $97 \%$ sequence similarity with targeted rumen bacteria such as $P$. ruminicola, $S$. ruminantium, $R$. flavofaciens, $S$. lutetiensis, and F. succinogenes, respectively.

\section{Discussion}

The extreme complexity of rumen microbiota is being understood and solved through various approaches of molecular biology and metagenomics for which good quality community DNA is of prime importance. Although methods can vary, all ascertain three major aims including comprehensive cell lysis, removal of non-nucleic acid components, and minimal loss of extracted nucleic acid [12]. In 
context to this, bead beating mediated cell lysis, and phenol-based DNA purification is among established protocols of many researchers [5,13]. Jin et al. [14] and Stiverson et al. [10] applied bead beating method and RBBC method for community DNA extraction. Whereas, Minas et al. [15], Popova et al. [16], and Bashir et al. [17] used phenol for community DNA purification. The present study does not recommend using bead beating and phenol. Rumen digesta of slaughtered goat was used to evaluate an effect of modified methods on its different fraction. Finally, the fractions giving optimal results were used for method optimization.

In this instance, EM1, EM2, and EM3 methods could not extract optimal quality community DNA from any of the fraction such as solid, liquid, or squeezed rumen digesta; though $10 \mathrm{mg} / \mathrm{ml}$ lysozyme application resulted into the highest yield of nucleic acid $(\mathrm{ng} / \mu \mathrm{l})$ from solid fraction. This emphasizes on the strongest association of microbial community with solid rumen digesta, where they must be present in highest abundance. Increasing lysozyme concentration up to $25 \mathrm{mg} / \mathrm{ml}$ could not improve it further which marks its poor efficacy in conclusion. Furthermore, the increase in sample size showed decreased yield which is a sign of increasing concentration of inhibitors. Here, $200 \mathrm{mg}$ sample size found most suitable.

In continuation to this; brownish, non-uniform DNA suspension followed by smearing in the agarose gel electrophoresis is indicative of non-feasibility of an enzymatic method for community DNA extraction. Rumen content samples contain many substances, such as tannins, that could inhibit the PCR. Relative absorbance readings $\left(\mathrm{A}_{260 \mathrm{~nm}} / \mathrm{A}_{230 \mathrm{~nm}}\right.$ for carbohydrates, aromatic compounds, humic acids, and phenolics; $\mathrm{A}_{260 \mathrm{~nm}} / \mathrm{A}_{280 \mathrm{~nm}}$ for protein) provide an indication of DNA purity and should ideally be 2.0 to 2.2 for $\mathrm{A}_{260 \mathrm{~nm}} \mathrm{~A}_{230 \mathrm{~nm}}$ and 1.8 for $\mathrm{A}_{260 \mathrm{~nm}} / \mathrm{A}_{280 \mathrm{~mm}}$ for most molecular biology applications [2,18]. Chen et al. [19] could get $\mathrm{A}_{260 \mathrm{~nm}}$ ' $\mathrm{A}_{280 \mathrm{~nm}}$ of 1.8 with community DNA extraction from Yak rumen digesta using SDS-lysozyme method. $\mathrm{A}_{260 \mathrm{~nm}} / \mathrm{A}_{280 \mathrm{~nm}}$ obtained in our study could not exceed beyond 1.3. This might indicate variable efficacy of community DNA extraction method in each different ruminant and respective rumen fractions.

To accomplish optimal quality DNA extraction, the chemical method performed in four sets of modifications such as CM1, CM2, CM3, and CM4 could extract community DNA with optimal purity ratios very efficiently. These methods are different from Henderson et al. [2], Yu and Morrison [20] which preferred column based DNA purifications. In continuation with this, Popova et al. [16] and Fliegerova et al. [21] applied bead beating in merge with community DNA technique employed. In our study, lysis buffer incubation with solid fraction at $65^{\circ} \mathrm{C}$ for $30 \mathrm{~min}$, $1 \mathrm{~h}$ and $2 \mathrm{~h}$ without bead beating application successively increased the nucleic acid concentration along with its purity. Furthermore, $0.2 \%-1 \%$ CTAB variation could give similar results where $1 \%$ CTAB found most efficient. $1 \%$ CTAB seems most suitable for removal of strong inhibitors which can otherwise affect the DNA integrity. Unlike to the enzymatic method, the chemical method could extract uniform, white and translucent community DNA which showed an intact band on agarose gel electrophoresis. $2 \%$ CTAB with $2 \mathrm{~h}$ incubation seems highly effective for removal of tannin and polyphenols which can affect the DNA quality and integrity. Comparative analysis of enzymatic and chemical method draws the major conclusion toward association of large abundance of microbial communities with a solid fraction of goat rumen digesta, followed by squeezed and liquid fractions.

In accordance with this, a combination of enzymatic and chemical method could not fulfill the objective of extracting community DNA with highest efficiency and performance. In contrast to enzymatic and chemical methods, their combination together could extract highest nucleic acid from squeezed rumen digesta where solid fraction could give average yield. However, similar to enzymatic method, it could extract community DNA having brownish, non-uniform suspension which failed to give a band on agarose gel electrophoresis. It seems that independent enzymatic method or its combination with chemical method may not give functional community DNA as required for molecular biology applications.

Combination of Enzymatic + Chemical + Physical method drawn a similar conclusion to EC method wherein highest nucleic acid was obtained from squeezed rumen digesta but with optimal purity ratios. Increase in a number of freeze-thaw cycles as a part of its modification could not improve it to a large extent. Three freeze-thaw cycles and 2\% w/v PVP 40 applications for squeezed rumen digesta achieved the optimal performance. Along with chemical method, it proved to be the second effective method to give community DNA extraction efficiently. Furthermore, suitability of ECPM2 toward squeezed rumen digesta may suggest its efficacy for distinct microbial consortia other than solid fraction. Collectively, CM4 and ECPM2 methods can possibly extract a good quality community DNA even without application of RNAase, phenol or any kit based column purifications. QIAamp DNA Stool Mini Kit (Qiagen, 51504) the only kit method studied here; could give highest nucleic acid in solid fraction than squeezed rumen digesta. Furthermore, lysis temperature of $90^{\circ} \mathrm{C}$ found most effective for efficient cell lysis. High temperature may help in efficient cell wall degradation of Gram-positive bacterial communities and thereby improve the yield.

Thus, community DNA extraction performed using QIAamp DNA Stool Mini Kit (Qiagen, 51504), methods EM1 and CM4 found most effective with solid rumen digesta. Methods ECM1 and ECPM2 showed efficient performance with squeezed rumen digesta. Apart from this, 1.5 months stored rumen sample showed a statistically significant drop in purity ratios 
of community DNA. The choice of DNA extraction method followed by sampling and storage may have an impact on the revealed community structure [22]. This is in agreement with Tatiana et al. [9] which shown that rumen sample storage can have influence over the yield of metagenomics DNA, abundances of specific phyla, class or other taxa and thus can change the picture of diversity indices and community richness. Although the change in diversity richness has been recorded for rumen samples, it's may not be the case for soil community DNA extraction where no any significant differences have been noticed in samples processed after preservation with respect to their DGGE profiles or DNA quality [23]. This emphasizes on criticality of rumen samples and methods to follow in.

Following this, community DNA extracted with CM4 and ECPM2 methods could give standard PCR amplification with universal bacterial primers and targeted bacterial 16S rRNA gene primers which prove its efficacy for a variety of molecular biology applications. Furthermore, PCR amplification of targeted bacteria with solid fraction and squeezed fraction of goat rumen digesta shows their strong association with rumen. It may denote different compatibility of each of the fraction for specific extraction method employed. 16S rRNA gene sequencing and identification of PCR amplified products confirmed the presence of $R$. flavofaciens, F. succinogenes, $S$. ruminantium, and $S$. lutetiensis in goat rumen. Along with this, P. ruminicola was detected against targeted genus Bacteroides and Prevotella. PCR and 16S rRNA based culture independent analyses are thus very informative and necessary to understand population wide community patterns [24-27]. In contrast, M. multacida was not detected in this study. This is in agreement with PersKamczyc et al. [28] and Li et al. [29] which stated that the presence of rumen microorganisms may vary as per their associated functions. This leaves a possibility of the presence of these undetected genera and species in different rumen fraction or current optimized methods may require extreme sensitive operations for their detection. In another way, noticing their presence through molecular biology needs more attention and methods establishment.

\section{Conclusion}

To the best of our knowledge, this is the first report of optimization of modified CTAB and CTABSDS-PVP-lysozyme-freeze-thaw methods for community DNA extraction from solid rumen digesta, its centrifuged supernatant and squeezed rumen digesta of a slaughtered goat. Furthermore, this study showed that short-term rumen sample preservation at $-80^{\circ} \mathrm{C}$ without any external preservatives does not affect the quality of community DNA though long-term sample preservation for 1.5 months does. Methods optimized in our study do not recommend the use of phenol, RNAase, proteinase $\mathrm{K}$ or kit based DNA purifications which differentiate them from others. Possible extraction of $>15 \mathrm{~Kb}$ community DNA from rumen confirms their efficacy for molecular biology applications. Consistent purity ratios, high nucleic acid yield, and PCR amenability stand out the reliability and reproducibility of these methods. Further, detection of P. ruminicola, S. lutetiensis, R. flavofaciens, S. ruminantium, and $F$. succinogenes in solid and squeezed rumen digesta proves their strongest association with rumen fiber mat. It also marks the presence of distinct microbial communities in solid and squeezed rumen fractions that, in turn, differs the performance of each different method employed and yield of nucleic acid obtained. It also leaves a possibility of the presence of difficult microbial consortia in squeezed rumen digesta whose DNA extraction methods need more attention. Finally, manual protocols of community DNA extraction may vary in different ruminant which suggests undertaking rigorous research in the development of new protocols.

\section{Authors' Contributions}

DA and AK designed the research; DA collected the samples, performed the research, analyzed data and prepared the manuscript, AK guided the entire research, data analysis, and manuscript preparation. All authors read and approved the final manuscript.

\section{Acknowledgments}

The authors are grateful to Symbiosis International University, Lavale, Pune for allowing perusal of Ph.D. The authors also thank Praj Industries Ltd., Pune, Maharashtra, India, and CTO, Praj Matrix, R \& D Center, Division of Praj Industries Ltd., Pune, Maharashtra, India, for permission to conduct research work at Praj Matrix. This research work has been conducted using internal research funds from Praj Industries Ltd., Pune, Maharashtra, India under project T-12009.

\section{Competing Interests}

The authors declare that they have no competing interests.

\section{References}

1. Griffiths, R.J., Whiteley, A.S., O'Donell, A.G. and Bailey, M.J. (2000) Rapid method for co extraction of DNA and RNA from natural environment for analysis of ribosomal DNA- and rRNA-based microbial community composition. Appl. Environ. Microbiol, 66(12): 5488-5491.

2. Henderson, G., Cox, F., Kittelmann, S., Miri, V.H., Zethof, M., Noel, S.J., Waghorn, G.C. and Janssen, P.H. (2013) Effect of DNA extraction methods and sampling techniques on the apparent structure of cow and sheep rumen microbial communities. PLoS One, 8(9): 1-14.

3. Henderson, G., Cox, F., Ganesh, S., Jonker, A., Young, W., Global Rumen Census Collaborators. and Janssen, P.H. (2015) Rumen microbial community composition varies with diet and host, but a core microbiome is found across a wide geographical range. Sci. Rep-UK., 5: 14567.

4. Klieve,A.V., O Leary, M.N., Mc Millen, L. and Ouwerkerk, D. (2007) Ruminococcus bromii, identification and isolation as a dominant community member in the rumen of cattle fed a barley diet. J. Appl. Microbiol., 103(6): 2065-2073. 
5. McSweeney, C.S., Denman, S.E., Wright, A.D.G. and Yu, Z. (2007) Application of recent DNA/RNA-based techniques in rumen ecology. Asian-Aust. J. Anim. Sci., 20(2): 283-294.

6. Rosero, J.A., Strosova, L., Mrazek, J., Fliegerova, K. and Kopecny, J. (2012) PCR detection of uncultured rumen bacteria. Folia Microbiol., 57: 325-330.

7. Kang, T.J. and Yang, M.S. (2004) Rapid and reliable extraction of genomic DNA from various wild-type and transgenic plants. BMC Biotechnol., 4: 20.

8. Vaidya, J.D., Bogertm, B.V.D., Edwards, J.E., Boekhorst, J., Gastelen, S.V., Saccenti, E., Plugge, C.M. and Smidt, H. (2018) The effect of DNA extraction methods on observed microbial communities from fibrous and liquid rumen fractions of dairy cows. Front Microbiol., 9: 1-16.

9. Tatiana, Y., Salcedo, G., Ramirez-Uscategui, R.A., Machado, E.G., Messana, J.D., Kishi, L.T., Dias, A.V.L. and Berchielli, T.T. (2017) Studies on bacterial community composition are affected by the time and storage method of the rumen content. PLOS One, 12(4), 1-15.

10. Stiverson, J., Morrison, M. and Yu, Z. (2011) Populations of select cultured and uncultured bacteria in the Rumen of sheep and the effect of diets and Ruminal fractions. Int. J. Microbiol., 2011: 1-8.

11. Tajima, K., Aminov, R.I., Nagamine, T., Matsui, H., Nakamura, M. and Benno, Y. (2001) Diet-dependent shifts in the bacterial population of the rumen revealed with realtime PCR. Appl. Environ. Microbiol 67(6): 2766-2774.

12. Lever, M.A., Torti, A., Eickenbusch, P., Michaud, A.B., Santl-Temkiv, T. and Jorgensen, B.B. (2015) A modular method for the extraction of DNA and RNA, and the separation of DNA pools from diverse environmental sample types. Methods, 6: 476.

13. Jami, E., Israel, A., Kotser, A. and Mizrahi, I. (2009) Exploring the bovine rumen bacterial community from birth to adulthood. The ISME J, 7: 1069-1079.

14. Jin, W., Cheng, Y. and Zhu, W. (2017) The community structure of Methanomassiliicoccales in the rumen of Chinese goats and its response to a high grain diet. J Anim. Sci. Biotech., 8: 47.

15. Minas, K., McEwan, N.R., Jamie, C. and Scott, N.K.P. (2011) Optimization of a high-throughput CTAB-based protocol for the extraction of qPCR-grade DNA from rumen fluid, plant and bacterial pure cultures. FEMS Microbiol. Lett., 325: 162-169.

16. Popova, M., Martin, C. and Morgavi, D.P. (2010) Improved protocol for high-quality Co-extraction of DNA and RNA from rumen digesta. Folia Microbiol., 55(4): 368-372.

17. Bashir, Y., Rather, I.A. and Konwar, B.K. (2015) Rapid and simple DNA extraction protocol from goat rumen digesta for metagenomic analysis. Pak. J. Pharm. Sci., 28(6): 2305-2309.
18. Lead, J.R., Starchev, K. and Wilkinson, K.J. (2003) Diffusion coefficients of humic substances in agarose gel and water. Environ. Sci. Technol., 37: 482-487.

19. Chen, Y.B., Lan, D.L., Tang, C., Yang, X.N. and Jian, L. (2015) Effect of DNA extraction methods on the apparent structure of yak rumen microbial communities as revealed by $16 \mathrm{~S}$ rDNA sequencing. Pol. J Microbiol., 64(1): 29-36.

20. Yu, Z. and Morrison, M. (2004) Improved extraction of PCR-quality community DNA from digesta and fecal samples. Bio Tech., 36: 808-812.

21. Fliegerova, K., Tapio, I., Bonin, A., Mrazek, J., Callegaric, M.L., Bani, P., Bayat, A., Vilkki, J., Kope_cny, J., Shingfieldd, K.J., Boyer, F., Coissac, E., Taberlet, P. and Wallace, R.J. (2014) Effect of DNA extraction and sample preservation method on rumen bacterial population. Anaerobe, 29: 80-84.

22. Andersen, A.W., Bahl, M.I., Carvalho, V., Kristiansen, K., Sicheritz-Ponten, T., Gupta, R. and Licht, T.R. (2014) Choice of bacterial DNA extraction method from fecal material influences community structure as evaluated by metagenomic analysis. Microbiome, 2(19): 1-11.

23. Zhao, F. and Xua, K. (2012) Efficiency of DNA extraction methods on the evaluation of soil micro-eukaryotic diversity. Acta Ecol. Sinica, 32: 209-214.

24. Ross, E.M., Moate, P.J., Bath, C.R., Davidson, S.R., Sawbridge, T.I., Guthridge, K.M., Cocks, B.G. and Hayes, B.J. (2012) High throughput whole rumen metagenome profiling using untargeted massively parallel sequencing. BMC Genet., 13(53): 1-14.

25. Nettmann, E., Bergmann, I., Mundt, K., Linke, B. and Klocke, M. (2008) Archaea diversity within a commercial biogas plant utilizing herbal biomass determined by $16 \mathrm{~S}$ rDNA and mcrA analysis. J. Appl. Microbiol., 105: 1835-1850.

26. Liu, J.H., Zhang, M., Zhang, R., Zhu, W. and Mao, S. (2016) Comparative studies of the composition of bacterial microbiota associated with the ruminal content, ruminal epithelium and in the faeces of lactating dairy cows. Microbial. Biotech., 9(2): 257-268.

27. Kang, S., Denman, S.E., Morrison, M., Yu, Z. and McSweeney, C.S. (2009) An efficient RNA extraction method for estimating gut microbial diversity by polymerase chain reaction. Curr. Microbiol., 58(5): 464-471.

28. Pers-Kamczyc, E., Zmora, P., Cieslak, A. and Szumacher-Strabel, M. (2011) Development of nucleic acid-based techniques and possibilities of their application to rumen microbial ecology research. J Anim. Feed Sci., 20: 315-337.

29. Li, M., Penner, G.B., Hernandez-Sanabria, E., Oba, M. and Guan, L.L. (2009) Effects of sampling location and time, and host animal on assessment of bacterial diversity and fermentation parameters in the bovine rumen. J. Appl. Microbiol., 107: 1924-1934. 